\title{
A Risk Management Method for the Operation of a Supply-Chain without Storage: - Supply Policy Optimization under Demand Risk -
}

\author{
Yasuhiro Kobayashi Member (Hitachi Res. Lab., Hitachi, Ltd.) \\ Yuuji Manabe Member (Hitachi Res. Lab., Hitachi, Ltd.) \\ Norimasa Nakata Non-member (Hitachi Res. Lab., Hitachi, Ltd.) \\ Satoshi Kusaka Non-member (Thermal \& Hydraulic Systems Division, Hitachi, Ltd.,)
}

Keywords : risk management, demand uncertainty, purchase optimization, power supply, supply chain

A business risk management method has been developed for a supply-chain without a storage function under demand uncertainty. Power supply players in the deregulated power market face the need to develop the best policies for power supply from self-production and reserved purchases to balance demand, which is predictable with error.

The proposed method maximizes profit from the operation of the supply-chain under probabilistic demand uncertainty on the basis of a probabilistic programming approach. Piece-wise linear functions are employed to formulated the impact of under-booked or over-booked purchases on the supply cost and the trade-off relation between purchase volume and supply cost for a case with transition dead zone. Constraints on over-demand probability are introduced to limit over-demand frequency on the basis of the demand probability distribution. Figure 1 illustrates the relation between predicted demand and supply policy, which specifies time-dependent reserved purchase volume. The linear programming technique is used to the constrained linear optimization problem.

The developed method has been experimentally applied to the supply policy of a power-supply-chain, the operation of which is based on 3-stage pricing purchase contract and on 28 time zones. Numerical results show the reserved volume larger than the value estimated from the expected demand, and sensitivity of demand predictability and over-demand aversions on the optimum reserved volume.

Figure 2 shows the optimum volume of reserved purchases subjective to over-demand continuation probability constraints. The characteristics of the obtained optimal supply policy are successfully captured in the numerical results, which suggest the applicability of the proposed method.

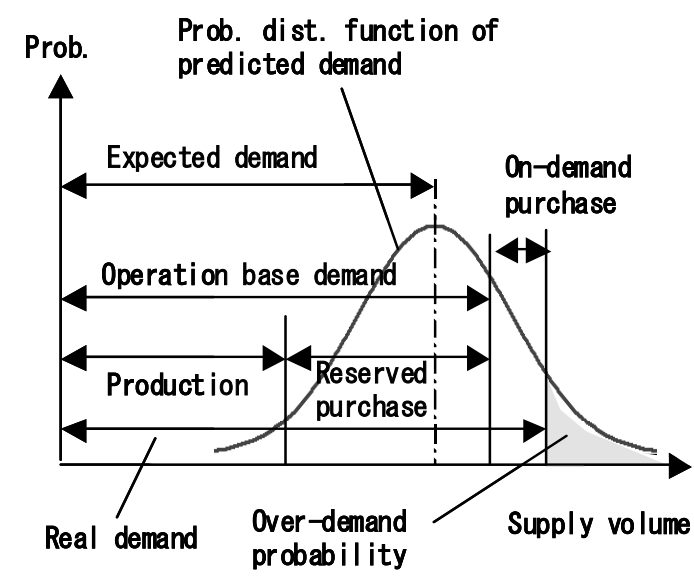

Fig. 1. Predicted demand and supply policy

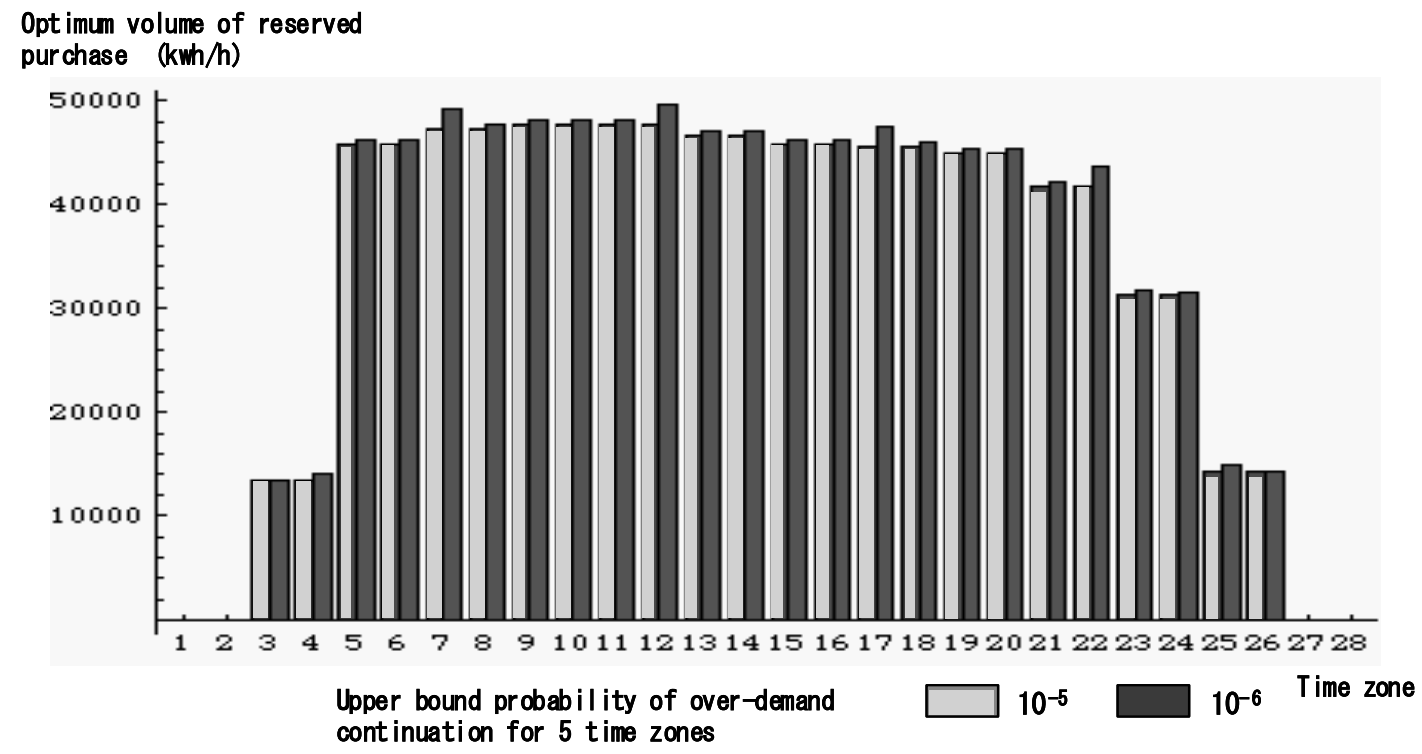

Fig. 2. The optimum volume of reserved purchase subjective to over-demand probability constraints 


\title{
在庫機能を持たないサプライチェーン運用のリスク管理手法 \\ 一需要リスクの下での運用計画最適化—
}

$\begin{array}{lllll}\text { 正員 小林 } & \text { 康弘* } & \text { 正員 } & \text { 真鍋 } & \text { 裕司* } \\ \text { 非会員 仲田 } & \text { 智将* } & \text { 非会員 } & \text { 日下 } & \text { 智** }\end{array}$

\author{
A Risk Management Method for the Operation of a Supply-Chain without Storage: \\ - Supply Policy Optimization under Demand Risk - \\ Yasuhiro Kobayashi*, Member, Yuuji Manabe*, Member, \\ Norimasa Nakata*, Non-member, Satoshi Kusaka**, Non-member
}

\begin{abstract}
A business risk management method has been developed for a supply-chain without a storage function under demand uncertainty. Power supply players in the deregulated power market face the need to develop the best policies for power supply from self-production and reserved purchases to balance demand, which is predictable with error. The proposed method maximizes profit from the operation of the supply-chain under probabilistic demand uncertainty on the basis of a probabilistic programming approach. Piece-wise linear functions are employed to formulate the impact of under-booked or over-booked purchases on the supply cost, and constraints on over-demand probability are introduced to limit over-demand frequency on the basis of the demand probability distribution.

The developed method has been experimentally applied to the supply policy of a power-supply-chain, the operation of which is based on a 3-stage pricing purchase contract and on 28 time zones. The characteristics of the obtained optimal supply policy are successfully captured in the numerical results, which suggest the applicability of the proposed method.
\end{abstract}

キーワード : リスク管理, 需要リスク, 調達最適化, 電力供給, サプライチェーン

Keywords : risk management, demand uncertainty, purchase optimization, power supply, supply chain

\section{1. はじめに}

サプライチェーンの運用 ${ }^{(1)(2)}$ には, さまざまなリスク要因 がかかわり，その事業収益がリスクに晒されるため, リス ク管理が重要となる。製造プラントを中心とするサプライ チェーンのリスク分析の研究は限られており, 電力供給を サプライチェーンと捉えれば，リスク管理が最も盛んに議 論されているサプライチェーンということになる。日本の 電力市場は, 2007 年度に向けて段階的に完全自由化され, 電力ビジネスに競争原理が導入される最中にある ${ }^{(3)}$ 。自由化 市場において, 電気事業者は, 収益が不安定となるため, 収益変動リスクの管理が大きな課題となっている。電力ビ ジネスのリスク管理に関しては, 電力自由化が進み, かつ

\footnotetext{
* (株)日立製作所日立研究所

干319-1292 茨城県日立市大夕力町 7-1-1

Hitachi Res. Lab., Hitachi, Ltd.

7-1-1 Omika-cho, Hitachi-shi, Ibaraki-ken 319-1292

** (株)日立製作所火力・水力事業部

干317-8511 茨城県日立市幸町 3-1-1

Thermal \& Hydraulic Systems Division. Hitachi, Ltd.,

3-1-1 Saiwai-cho, Hitachi-shi, Ibaraki-ken 317-8511
}

金融技術でも先行した欧米において，金融工学を用いたリ スク管理技術の開発が行われている(4) (7)。しかし, コーポ レートレベルのリスク管理が中心であり, オペレーション レベルまで踏み込んだ検討は少ない( ${ }^{(8)}$ 。

電力供給の特徵は, 電力を貯蔵することが難しく, 在庫 機能を持たないサプライチェーンであることである。その ため, 需要リスクが最も重要なリスク要因となる。需要リ スクに関しては, 従来から需要予測の精度向上に種々の工 夫がなされているが(9), それを受けたシステム運用に関して は, 需要期待值に基づく最適運用を検討するアプローチに 限られていた ${ }^{(10)}$ 。

本論文では, 電力自由化市場の新規プレーヤである特定 規模電気事業者のサプライチェーンに注目する。電力会社 (一般電気事業者) が, 大規模な設備を有し, 多様な需要特 性を有する顧客に大量の電力を供給するサプライチェーン を運用するのに比し, 新規プレーヤの供給規模（自由化範 囲の $\left.2 \%{ }^{(11)}\right)$ は限られている。それ故に, 需要の統計的予測 が難しくなる側面は否めない。したがって, ある程度の予 
測誤差を前提として最適なシステム運用を計画する現実的 なアプローチが不可欠となる。このような背景の下，需要 の不確実性を確率事象として捉え, 需要リスクを対象とし, 線形計画法 ${ }^{(12)}$ をベースとする確率計画法に基づいてサプラ イチェーン運用計画の最適化を試みる(13) (15)。

本研究の目的は, 需要変動のリスクの下で在庫を持たず に自社生産と予約調達を併用するサプライチェーンの運用 計画を最適化する手法を開発することである。ここで，予 約調達とは，供給事業者が資材・部品・製品を自社で生産 して供給するだけでなく，前もって予約する形で固定量を 外部事業者から調達する方式である。

\section{2. サプライチェーンの運用計画}

〈2·1〉 在庫機能を持たないサプライチェーン 変動 する需要 (Demand) を満たすように資材・部品・製品を供 給するビジネスには, 自社で生産 (Self production) するとと もに，外部の生産者から調達して供給 (Supply) する形態が ある。図 1 に, 生産と調達により需要-供給をバランスさせ るサプライチェーンの形態を示す。このサプライチェーン には，在庫の機能が含まれない。

電力に代表されるような貯蔵できない間接材は在庫での 調節が難しい。そのため, 需要を予測し, 自社の生産計画 を立てる一方で，外部から調達できるよう契約を結び，需 要に合わせて事前(計画時)に予約することがある。以下で は，外部からの調達量を事前に確定することを予約調達 (Reserved purchase) と称する。予約調達は，事前に予約した 以上，購入する義務があり，一種の先渡し取引である。予 約調達により，需要が確定せずに時として自社生産の設備 容量を超えるケースに対応もできることになるので，事業 者は, 需要のピークに合わせて自社設備を確保する必要が なくなり，ビジネスを効率化できる。

実際の需要 (実需要) は, 需要予測誤差のため, 計画と 相違することになるが，自社の生産計画の変更により対応 できる場合，対応できない場合がある。対応できない場合， 外部からの調達量を変えざるを得ない。このような変更に は，通常それなりの追加コストがともない，調達を増やす 場合と減らす場合で, 追加コストも異なってくる。例えば,

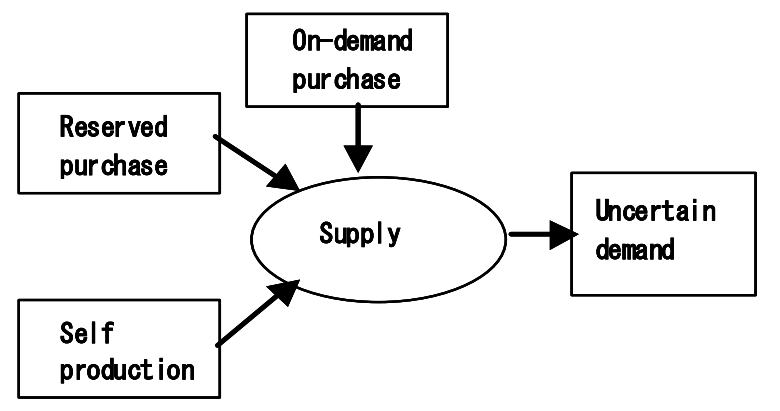

図 1 需要と供給のバランス

Fig. 1. Balance between demand and supply
調達を緊急に増やす場合 (On-demand purchase) の追加コス トが相対的に大きい場合, 実需要が計画時の想定需要を上 回るリスクを抑制するため, 需要誤差を見込んで計画す心゙ きである。

一般に, 外部からの調達単価は, 自社の生産単価を上回 る。このため, 供給コストに関し, 予約調達量のトレード オフが想定される。予約調達量の選択は, 需要リスクの存 在するサプライチェーンの事業収益を大きく左右すると言 える。

需要が確定したときの予約調達量と供給コストの関係を 図 2 に示す。この図は, 想定需要が正確でない限り（需要 予測が誤差を含む限り) 調達不足 (Under-booked supply) あ るいは調達過剩 (Over-booked supply) となること, 調達不足 も調達過剰も供給コストの上昇を招くこと, 想定需要がダ ウンサイドあるいはアップサイドに外れた場合には事業収 益を損なうことになるが，そのコストへの影響は必ずしも 対称とはならないことを示している。

リスク管理という観点から, 自社の生産計画の変更だけ では需要と供給のバランスが保てないケースへの対応とし て，二つのアプローチが考えられる。

（1）緊急調達緊急に追加調達でき, その量に限界が ない場合, 調達不足は, 需要と供給のバランスを保てるの でコストの問題である。しかし，このような事態（想定需 要超過）が生ずる確率を許容限界にコントロールする制約 条件を導入することができる。緊急調達に限界がある場合， 需要と供給のバランスを保てなくなるリスクを抑制するた め, よりきびしい想定需要超過制約が必要となる。

（2）供給停止 あらかじめ想定需要超過が生ずる可 能性を想定して，供給の停止を前提とする契約を結んでい る場合, 契約の条件にしたがって, 供給停止により需要と 供給のバランスを保つことができる。

わが国の電力市場では, 電力供給力の圧倒的な違いを背 景として, 特定規模電気事業者は, 相対契約ベースで, 電 力会社から予約調達, 緊急調達が可能であり, また供給停 止（負荷遮断）については一般的ではない状況にある。し たがって, 本研究では, 緊急に追加調達でき, 実質的にそ の量に限界がない場合を想定するが, 同時に想定需要超過

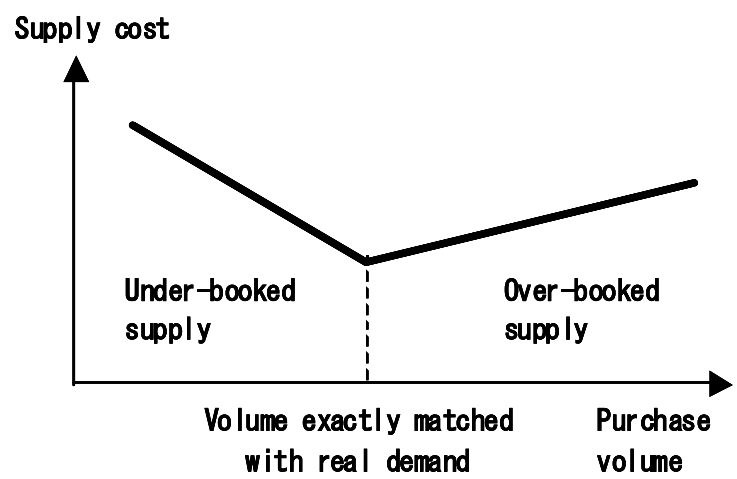

図 2 調達量と供給コストの関係

Fig. 2. Relation between purchase volume and supply cost 
制約を扱うことにする。

\section{〈2·2〉 サプライチェーンとしての電力供給}

（1）サプライチェーン運用条件 電力供給のサプラ イチェーンの運用では, 需要予測に基づいて, 前日に自社 の発電プラントの運転計画と予約調達の計画を立てるもの とする。したがって, 予約調達の意思決定は, 需要リスク の制御手段として翌日の運用計画の一環として行われる。

電力供給のサプライチェーンは, 需要, 生産, 調達の各 要素に次のような特徴を有する。

(a) 需要 供給先の顧客需要には, 需要予測の誤差に 対応した不確実性がある。計画時に, 需要を確率分布とし て予測できるが，予測值には誤差がともなう。需要予測に ついては，先行して開発した手法(15)を適用し，その結果よ り予測誤差の確率分布を推定することにする。予約調達の 最適化では, 需要リスクの確率分布は, 入力データとなる。

(b) 生産自社発電設備, あるいはそれに準ずる発電 設備による発電が, これに相当する。計画に際しては, 設 備の定格容量ではなく, 起動停止計画から自社生産の上限 が決まる。

(c) 調達電力会社あるいは自家発電事業者との契約 ベースでの予約調達が，これに相当する。予約調達量につ いては，通例，上限值が設定されることになる。

（2）需要リスク ここで注目するリスク要因は, 当日 にならないと顧客の電力需要が確定しないことである。結 果として, 当日の実需要に対して予約調達を多めに予約し た場合，予約した量だけ買う義務があるので，需要が低め に振れた場合, 計画を下回る出力で自社発電プラントを運 用せざるをえない。予約調達の単価が自社生産の単価より も高いとすると，供給コストが高くなる。

逆に, 結果として, 当日の実需要に対して予約調達を少 なめに予約した場合, 予約調達と自社生産だけでは需要を まかないきれず, 緊急に追加調達する必要に迫られる。当 然, 緊急調達の単価は, 自社生産や予約調達の単価よりも 高いので，供給コストが高くなる。当日の実需要がどうな るかは，前もって正確に知ることはできないが，予測手段 を用いて確率的に予測することができる。そのときの予測 誤差は, 予測性能の分析を通じて, 確率分布として定量的 に捉えることができる。

（3）コストと収益＼cjkstart電力供給のサプライチェーンは, 事業収益の最大化を目的関数として運用するものとする。 事業収益を売上げから供給コストを差し引いたものと定義 すると, 計画時の売上げは, 需要の確率分布に基づく需要 期待值に供給単価を乗じたものであり, 計画時の供給コス 卜は, 自社生産, 予約調達, 緊急調達を合わせた供給コス 卜期待值である。需要期待值や供給単価は既知であり, 計 画時の売上げは定数となるので, この場合, 事業収益の最 大化は，供給コストの最小化に他ならない。

ここでは, 基本的には, 緊急調達により需要リスクへの 対処が可能であり, 緊急調達の単価は, 当然, 自社生産や 予約調達の単価を上回り, 自社生産の単価は予約調達の単
価よりも低いと想定する。

ただし, 場合によっては, 予約調達から緊急調達への切 替えに関して，一定量の遷移区間を設定することがあり， この区間内では, 緊急調達の単価は抑制された水準に留め ることになる。この場合, 緊急調達に 2 段階があると見な すことができる。

また, 自社生産, 予約調達, 緊急調達の単価は, その量 に依らず一定とする。電力供給のサプライチェーンにおい て, 大規模事業者は, 性能が異なる数十台の発電機 (火力 プラント）の出力負荷の組合せを調整する経済負荷配分 ${ }^{(10)}$ を計画する。そのため, 自社生産単価は, 供給量の影響を 受ける。ここでは, 小規模なサプライチェーンを対象とす るため, 自社生産単価が生産量に依存しないものとして扱 う。

自社生産が，外部の設備保有者との長期契約による発電 である場合には，単価一定として扱うことができる。自社 生産に, コスト性能が出力負荷に強く依存する設備, ある いはコスト性能が著しく異なる複数の設備を有し, 単価が 生産量に影響される場合においても, 予約調達の単価を超 えないという前提であれば, 運用方策の解は, 大きく変わ ることはないものと考えられる。その場合, 単価一定とし て自社生産量を決め, 出力負荷を反映してコストを再計算 したり, 複数設備の間での負荷配分を決めることで, 計画 をより精緻なものにできる。

（4）想定需要超過の回避 想定需要超過が短期的に 発生することも大きなリスク要因であるが, それが継続し て緊急調達が長時間に亘る場合, 緊急調達先にとってもイ ンパクトが大きいため, さらに大きなリスク要因となると 想定される。したがって, 想定需要超過の継続に関しては, 調達コストに反映させるだけでなく, 想定需要超過が長時 間に亘るイベントについて, その生起確率を許容值以下に 制限する制約条件を扱う。

\section{3. 予約調達の最適化}

〈3·1〉 モデルの前提条件 電力供給のサプライチェ ーン・モデルに関し, 想定需要超過およびその確率の概念 や供給コストの特性を説明する。説明の便宜上, 運用の前 日に計画を立てるものとし, 時間要因を考慮しない 1 時点 モデルと時間要因を考慮した多時点モデルに分けて記述す る。1 時点モデルでは，1つの時区間（翌日の平均）を想定 し, 需要リスクの下で, 事業収益を最大化（あるいは供給 コストを最小化）する目的関数, 想定需要を超過する確率 に関する制約条件を用いる。

次いで, 時間要因を考慮したモデルに言及する。多時点 モデルでは, 複数の時区間（翌日の複数の時間帯）を想定 する。目的関数については, 個々の時区間の総和となり，1 つの時区間での想定需要超過確率に関する制約条件につい ては, 個々の時区間に課される。複数の時区間に亘る想定 需要超過の継続に関する制約条件（後出）については，時 区間をカップルした扱いが必要となる。 


\section{〈3·2〉 最適化モデル}

（1）変数 まず, 1 時点に注目して変数の関係を記す。 計画時点での自社生産量を $\mathrm{S}$, 予約調達量を X, 実行時点で の需要 (実需要) を Q とする。予約調達量 X が独立変数と なる。計画時点での需要は, 予測誤差の確率分布を $\mathrm{n}$ ノー ドの離散分布で近似的に表現して, 期待值 $\mathrm{Q}$ と係数 $\mathrm{Rm}$ $(\mathrm{m}=1, \cdots, \mathrm{n})$ を用いて，需要 $\mathrm{Rm} \underline{\mathrm{Q}}$ ととの值を取る確率 $\mathrm{Pm}$ の組で与えることができる。

図 3 は, 予測誤差のために翌日の実需要が異なるケース の供給の状況, すなわち実需要に応じた調達オペレーショ ンの様子を示している。図 3(a)では, 予測誤差を考慮して, 前日の予測結果から想定需要 (Plan basis demand) および予 約調達を決めている。想定需要とは, 自社生産の上限值と 予約調達量を加えたものである。図 3(b)では, 予測対象時点 (翌日) における需要の確率分布を，9ノードの離散分布で 表現している。需要の確率分布は, 需要期待值 (Expected demand) と予測誤差の確率分布から定める。需要がアップ サイドに大きく振れた場合（図 3(b)で需要量 Q8 および Q9 のケース）には, 自社生産と予約調達では需要をカバーし きれない想定需要超過が生じ, 緊急調達が必要となる。こ の計画の想定需要超過確率 (Under-predicted or over-demand probability) は P8+P9 となる。

時間とともに変わる需要を扱う場合, 多時点モデルで計 画を作成する。1 日を $\mathrm{K}$ 時点とする場合, 時区間 $\mathrm{k}(1,2, \cdots$, $\mathrm{K})$ での自社生産量を $\mathrm{Sk}$, 予約調達量を $\mathrm{Xk}$, 実需要を $\mathrm{Qk}$
とする。予約調達量 Xk が独立変数となる。図 4 は, 多時点 モデルでの時区間ごとの供給計画の例を示しており, 予測 誤差のために実需要がアップサイドに振れた場合に備え て, 想定需要を需要期待值よりも大きく設定している。こ の図は，時区間ごとに計画する予約調達量と需要予測期待 值との関係, 想定需要超過確率の許容範囲と調達予約量の 関係を示している。想定需要超過確率は, 需要期待值と誤 差の確率分布から算出され, 図中の 5 時区間に対して, $\mathrm{P}(08: 00), \mathrm{P}(10: 00), \mathrm{P}(12: 00), \mathrm{P}(14: 00), \mathrm{P}(16: 00)$ として与え られている。

（2）目的関数 ここでも，まず，1 時点に注目して目 的関数を記す。まず，供給コストの最小化に着目する。 $\mathrm{S}$ お よび $\mathrm{Q}$ が与えられれば，供給コスト $\mathrm{f}$ は X の関数となる。

$\mathrm{Ks}, \mathrm{Kx}, \mathrm{Kp}$ は, それぞれ, 自社生産, 予約調達, 緊急調達 の単価とする。

(a) 需要が大きい場合 : $Q \geqq S+X$

追加コストを支払って不足分を緊急調達する。

$$
\mathrm{f}=\mathrm{Ks} \mathrm{S}+\mathrm{Kx} \mathrm{X}+\mathrm{Kp}(\mathrm{Q}-\mathrm{S}-\mathrm{X})
$$

(b) 需要が小さい場合 : $Q<S+X$

自社の生産を抑制する。

$\mathrm{f}=\mathrm{Ks}(\mathrm{Q}-\mathrm{X})+\mathrm{Kx} \mathrm{X}$

したがって, 実需要に対する供給コストは, 図 5(a)に示した ように 2 段階の折れ線関数となる。実需要は翌日まで確定 しないので, 供給コストは, 需要の確率分布に関する期待 值であり, $\mathrm{Q}$ を $\mathrm{Rm} \underline{\mathrm{Q}}$ で置き換えた $\mathrm{n}$ 通りのコスト曲線（折

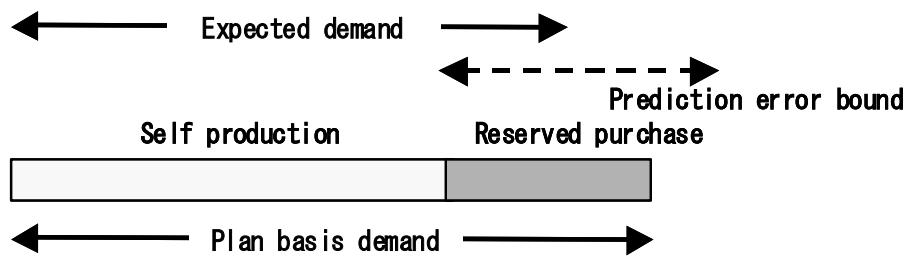

(a) Predicted demand based reservation

Demand

Prob. Dist. of demand

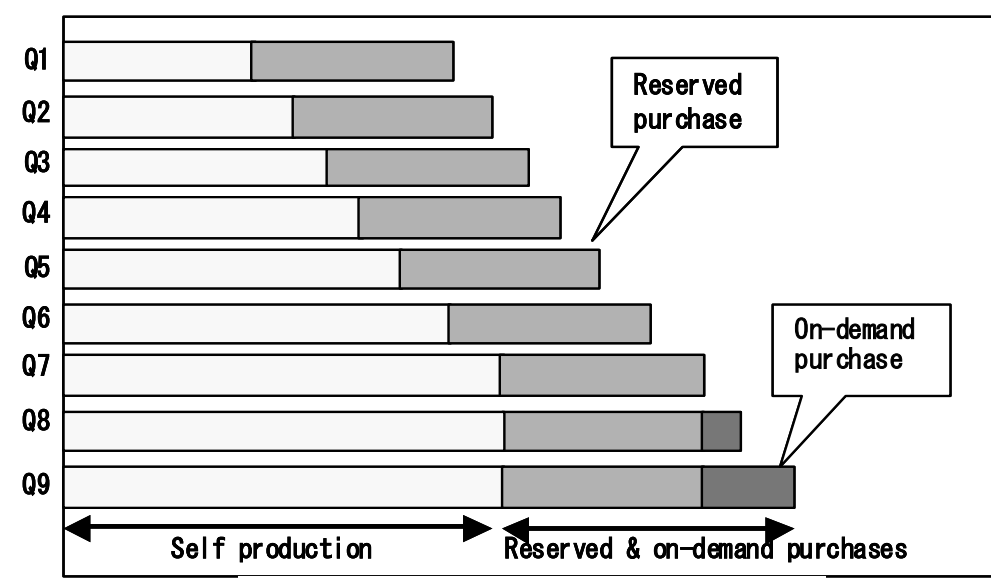

(b) Real demand based supply policy

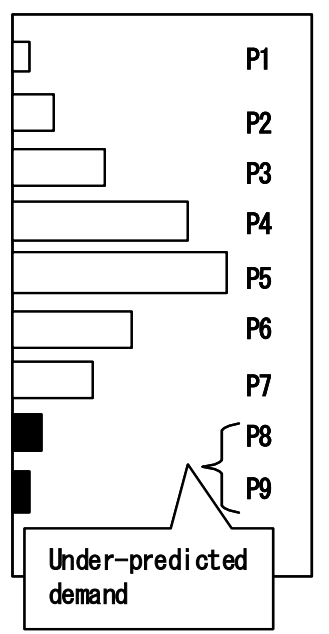

demand

図 3 実需要に応じた調達オペレーション

Fig. 3. Real demand based supply operation 


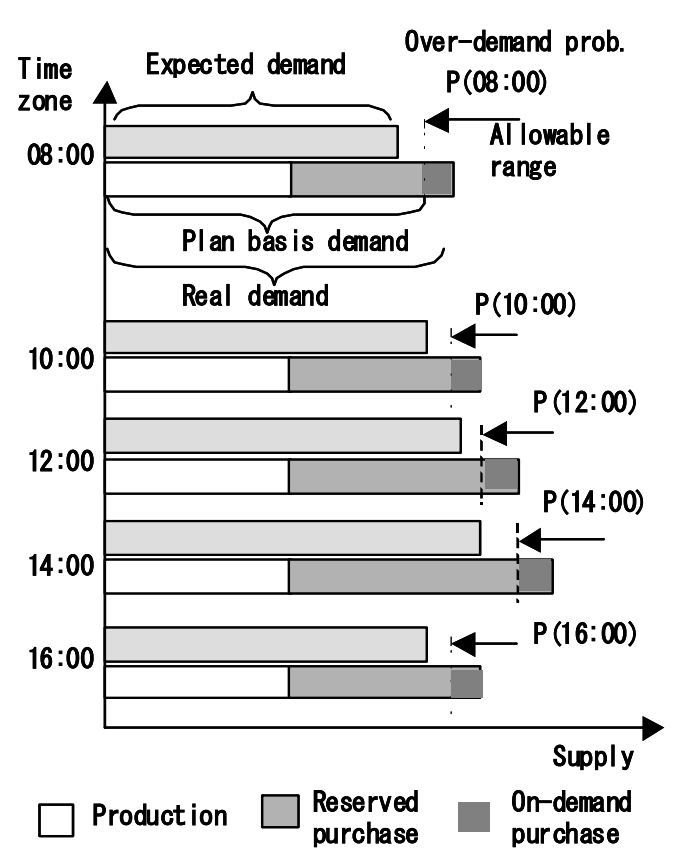

図 4 時区間ごとの供給計画の例

Fig. 4. Illustrated time-wise supply policy

れ線）を，生起確率 Pm を重みとして加え合わせた関数とな る。

以上に記したモデルでは, 緊急調達の価格が一様 (1 段階) であり，実需要に対する供給コストは 2 段階の折れ線関数 となる。予約調達から緊急調達への切替えに関し許容誤差 (Transition dead zone) を設定する場合, 緊急調達の価格が 2 段階となり, 実需要に対する供給コストは図 5(b)に示すよう に 3 段階の折れ線関数となる。実需要から自社生産分を減 じた外部調達量は, (1)緊急調達が不可欠な予約不足領域,

(2)許容誤差の範囲でバランスできる領域, (3)自社生産を抑 制する調達過剰領域にケース分けできる。図 5(c)に, 予約調 達に関し遷移区間を設定する場合の領域別コスト関数を示 す。

ここでは，事業収益（目的関数）は売上高から供給コス トを差し引いたものであり, 前者は需要に比例して一定と なるので, 外部調達量と事業収益の関係は, 外部調達量と 供給コストの関係から決まることになる。

次に，全時区間に亘る事業収益の最大化を想定する。こ れは，それぞれの時区間での事業収益の総和であり，目的 関数は線形関数となる。

（）想定需要超過の制約条件＼cjkstart想定需要超過には, 時 区間ごとに課される条件と, 複数の時区間に亘って課され る条件がある。通例, 長期に亘る想定需要超過は, 短期の 想定需要超過に比してより厳しく発生回避が求められる。 例えば，時区間当たりの想定需要超過が 10 回に 1 回許され ても，連続した 2 時区閒に亘る想定需要超過は，1000回に 1 回しか許されないという状況もありうる。

ここでは，まず，単独の時区間（1 時点モデル）に着目し て想定需要超過を扱う。想定需要超過確率 (Over-demand

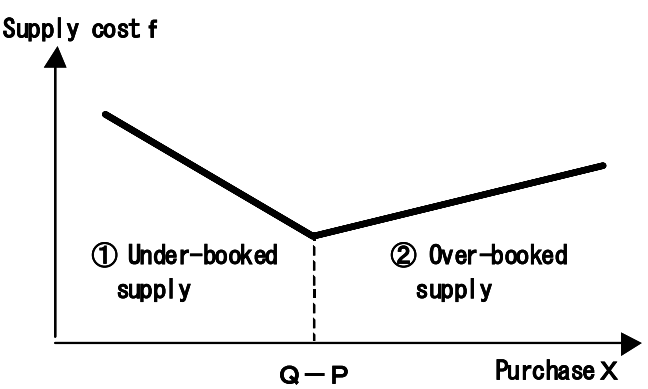

(a) Without transition dead zone

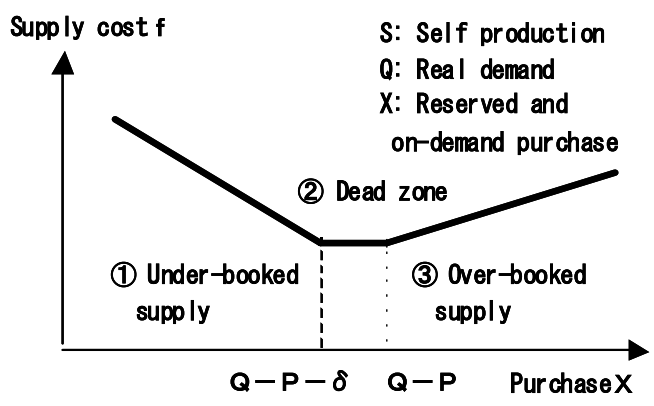

(b) With transition dead zone

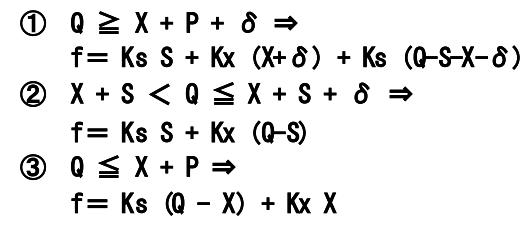

(c) Piece-wise cost function for case (b)

図 5 調達量と供給コストの関係

Fig. 5. Relation between purchase volume and supply cost

probability) は分布のアップサイドのテイルに関する小さな 值となるので, 離散分布で扱うのは必ずしも得策ではない。 図 6 に, 需要予測と供給不足（想定需要超過）の関係を示 す。ここでは，予測誤差の分布に正規分布，時区間当たり の予測誤差の独立性を仮定して, 想定需要超過確率の上限 制約から想定需要の下限值（これ以上を想定しないと想定 需要超過確率が過大となる) を決めて, 予約調達量の下限 值を設定する。

いま，ある時区間における想定需要（自社生産量 $\mathrm{S}+$ 予 約調達量 X）と時区間の想定需要超過確率 $\mathrm{P}$ を関係付ける。 以下で変数 Z は, 時区間の想定需要超過確率の対数と線形 関係にある補助変数であり, 関係式 $S+X=(2-Z) \underline{Q}$ を満 たすものとする。 $\mathrm{P}=\operatorname{Exp}[\mathrm{a} Z+\mathrm{b}]$ で想定需要超過確率を近似 し, その上限值を Px とすると, 次式が得られる。

$$
\mathrm{P} \leqq \mathrm{Px} \quad \Rightarrow \quad \log [\mathrm{P}]=\mathrm{a} Z+\mathrm{b} \geqq \log [\mathrm{Px}]
$$

図 7 に，予測誤差の累積分布関数を指数関数で回帰した 場合の計算例を示す。この生起確率 $\mathrm{P}$ の対数と変数 $\mathrm{Z}$ の関 係を用いて, 時区間ごとの想定需要超過確率の上限（モデ ルリスク対応の必要に応じては下限も）に関する制約条件 を, 変数 Z の下限 (上限) に関する制約条件に書き換える ことができる。したがって, 想定需要超過確率に関する上 


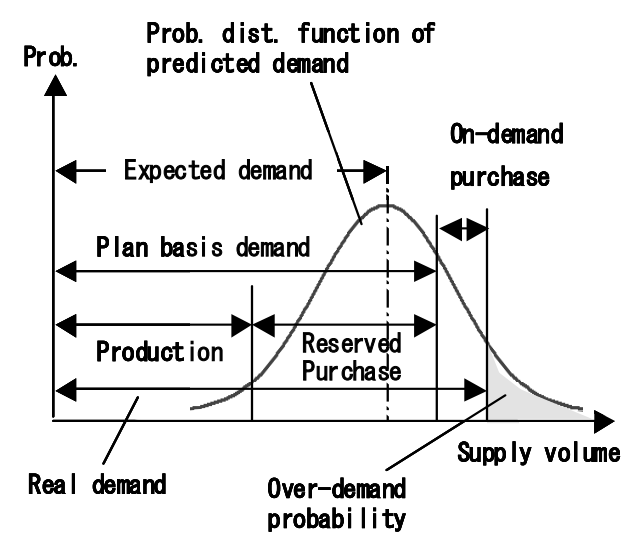

図 6 需要予測と供給不足の関係

Fig. 6. Predicted demand and supply policy

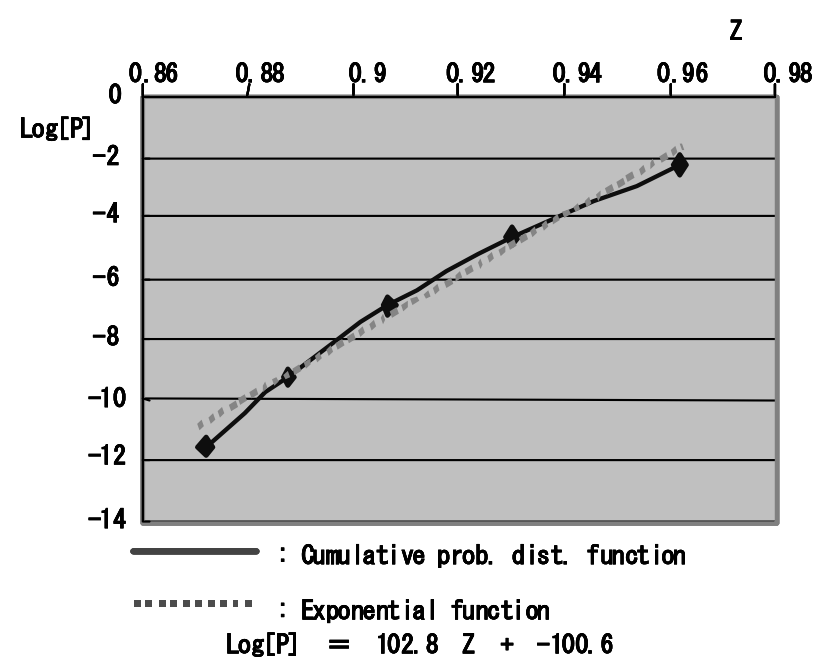

図 7 累積分布関数の指数関数による近似

Fig. 7. Sample approximation function for cumulative prob. dist

限制約は，予測誤差の確率分布を元に予約調達の下限制約 に還元されることがわかる。

多時点モデルでは，個別の時区間の制約条件を同時に扱 うことになる。

（4）想定需要超過継続の制約条件 次に, 想定需要超 過の状態が継続 (Over-demand continuation) して複数の時区 間（多時点モデル）に亘る事象に関する制約条件を記述す る。それぞれの時区間ごとに，想定需要超過の発生をどこ まで許容するかという確率に関する上限制約は，上記のよ うに，想定した予測誤差の確率分布を元に，予約調達量の 下限制約として還元される。

時区間ごとの想定需要超過確率の対数と線形関係にある 補助変数を用いることにより，複数の時区間に対する想定 需要超過確率に関する制約条件を表わせる。いま, 図 4 の 1 日（5 時区間）の各時間帯に対し制約が課されるとする。そ の条件は，上限值を Pz とし，各時区間での予測誤差が独立 であるとして，次のように表わされる。
$\mathrm{P}(08: 00) \mathrm{P}(10: 00) \mathrm{P}(12: 00) \mathrm{P}(14: 00) \mathrm{P}(16: 00) \leqq \mathrm{Pz}$

$\log [\mathrm{P}(08: 00)]+\log [\mathrm{P}(10: 00)]+\log [\mathrm{P}(12: 00)]$

$+\log [\mathrm{P}(14: 00)]+\log [\mathrm{P}(16: 00) \geqq \log [\mathrm{Pz}]$

時区間ごとの生起確率は, 補助変数の線形関数に近似でき るので, 想定需要超過の継続を回避するための制約条件は 線形不等式制約として記述できる。

〈3·2〉最適化の計算方法 供給コストの関数に現れ る折れ線(区分線形)の関数は, 補助変数を導入して線形計画 法 ${ }^{(13)}$ により解くことができる。この折れ線関数自体は, 絶 対值関数と直線の組合せから合成することができる。絶対 值関数を線形計画で扱う方法は, 投資ポートフォリオ最適 化に対して提案されている絶対偏差モデル等で用いられて おり，そのテクニックを適用できる ${ }^{(16)}$ 。

（1）区分線形の供給コスト 以下に, 予約調達から緊 急調達に変わる際に遷移区間を設定するケース（3 段階の折 線）に関し, 供給コストの関数を記述する。1 時点モデルで 目的関数とする時区間の収益 PF は, 供給単価を $\mathrm{Kd}$, 需要

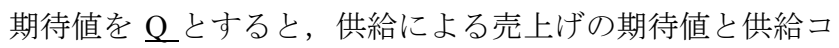
スト期待值 Yから，次のように表わせる。

$\mathrm{PF}=\mathrm{Kd}_{\mathrm{d}} \mathrm{Q}-\mathrm{Y} \rightarrow$ Max.

図 5(b)の 3 領域における供給コストは, 図 5(c)から, 次の ような制約条件を用いて表現する。以下において，Y1，Y2， Y3 は供給コストを表わすための補助的コスト関数であり, $\mathrm{u}, \mathrm{v}, \mathrm{w} 2, \mathrm{w} 3$ は折線を扱うための補助変数である。

$$
\begin{aligned}
& \mathrm{Y} 1=\left(\mathrm{K}_{\mathrm{X}}-\mathrm{Ks}\right) \mathrm{X}+\mathrm{K}_{\mathrm{X}} \delta+\mathrm{K}_{\mathrm{S}}(\mathrm{Q}-\delta) \\
& \mathrm{Y} 2=\mathrm{w} 2+\mathrm{u} \\
& \mathrm{Y} 3=\mathrm{w} 3+\mathrm{v} \\
& \mathrm{u}=(1 / 2)\left(\mathrm{Kp}-\mathrm{K}_{\mathrm{X}}\right)(\mathrm{X}+\mathrm{S}+\delta-\mathrm{Q}) \\
& \mathrm{v}=(1 / 2)\left(\mathrm{K}_{\mathrm{X}}-\mathrm{K}_{\mathrm{S}}\right)(\mathrm{X}+\mathrm{S}-\mathrm{Q}) \\
& \quad-\mathrm{w} 2 \leqq \mathrm{u} \leqq \mathrm{w} 2 \\
& \quad-\mathrm{w} 3 \leqq \mathrm{v} \leqq \mathrm{w} 3
\end{aligned}
$$

ここで, Y1, Y2, Y3 は, 図 5(b)の折れ線のコスト関数 Y の一部をなす直線部分(1), (2), (3)のそれぞれに対応して定 義されており，次のような関係がある。

・区間(1)の供給コスト関数 $(\mathrm{Y} 2=0, \mathrm{Y} 3=0): \mathrm{Y}=\mathrm{Y} 1$

・ 区間(1)(2)の供給コスト関数(Y3=0): $\mathrm{Y}=\mathrm{Y} 1+\mathrm{Y} 2$

・ 区間(1)(2)(3)の供給コスト関数 : $\mathrm{Y}=\mathrm{Y} 1+\mathrm{Y} 2+\mathrm{Y} 3$

（2）収益期待值予約調達量を独立変数として，1日 （n 時区間）の事業収益の確率的な最大化は, 以下のように 定式化できる。

・需要予測值が Q であるとき, 実需要は, それぞれ生起確 率 P1，P2，P3，... Pn で，Q1，Q2，Q3，..., Qn となる。 それぞれの需要 $\mathrm{Qk}$ に対応して, 自社生産量 $\mathrm{Sk}$, 緊急調達 量 Wk が決まる。

・供給コストの期待值は, それぞれの需要 $\mathrm{Qk}$ に対して, 自 社生産量 $\mathrm{Sk}$, 予約調達量 $\mathrm{X}$, 緊急調達量 $\mathrm{Wk}$ から決まる供 給コスト $\mathrm{fk}$ を用いて， $\Sigma \mathrm{Pkfk}(\mathrm{Qk}, \mathrm{Sk}, \mathrm{X}, \mathrm{Wk})$ となる。

・売上高の期待值は, それぞれの実需要 $\mathrm{Qk}$ に対して, 売上 
高が $\mathrm{Kd} \mathrm{Qk}$ となるため, $\mathrm{Kd} \Sigma \mathrm{Pk} \mathrm{Qk}=\mathrm{Kd} \underline{\mathrm{Q}}$ となる。した がって，時区間の事業収益の期待值は次式となる。

$\mathrm{PF}=\Sigma\{\mathrm{Kd} \mathrm{Pk} \mathrm{Qk}-\mathrm{fk}(\mathrm{Qk}, \mathrm{Sk}, \mathrm{X}, \mathrm{Wk})\}$

複数の時区間に亘る多時点モデルで, 事業収益を最大化 する場合には，時区間ごとの事業収益の総和を最大化する。

\section{4. 予約調達最適化への適用}

〈4·1〉 1 時区間の最適化 ケーススタディの評価条 件を以下に示す。翌日を 1 時区間（代表的な半時間）で扱 う。

・自社生産 (発電) 量 : $40000 \mathrm{kWh} / \mathrm{h}$

・翌日需要の期待值 : $80000 \mathrm{kWh} / \mathrm{h}$

- 翌日需要の予測精度 : 誤差の分布は正規分布とし, 標準 偏差 $5 \%$ で予測可能

・予測誤差の確率分布は，9ノード離散分布で近似

・予約調達から緊急調達の切替えに， $5000 \mathrm{kWh} / \mathrm{h}$ 裕度を仮 定

• 想定需要超過許容度（想定需要超過確率の上限值）：0.001 以下（1000 時区間に 1 回の発生までを許容）

- 生産・外部調達・供給単価として, 生産単価 : 10 円/予約 調達単価 : 15 円/緊急調達単価 : 30 円/供給単価 : 20 円を 仮定

〈4·2〉 1 時区間の計算結果 1 時区間のケースにおい て予約調達量と事業収益の関係を図 8 に示す。制約条件か ら決まる想定需要超過確率の下限 (Lower bound) より高い (Allowable probability) 領域（制約内点）で，最適予約調達 量が与えられている。これは, 調達過剰サイドよりも調達 不足サイドで事業収益の低下が大きいため, 予約調達量が 大きい方が確率的に収益を最大とするためである。この非 対称性は, 予約調達量の選択において, 需要期待值をもつ て想定需要を決めることが得策でないことを示唆してい る。予測誤差が大きいほど, 需要期待值を想定需要とした ときの予約調達量と最適予約調達量の乘離は大きくなる。

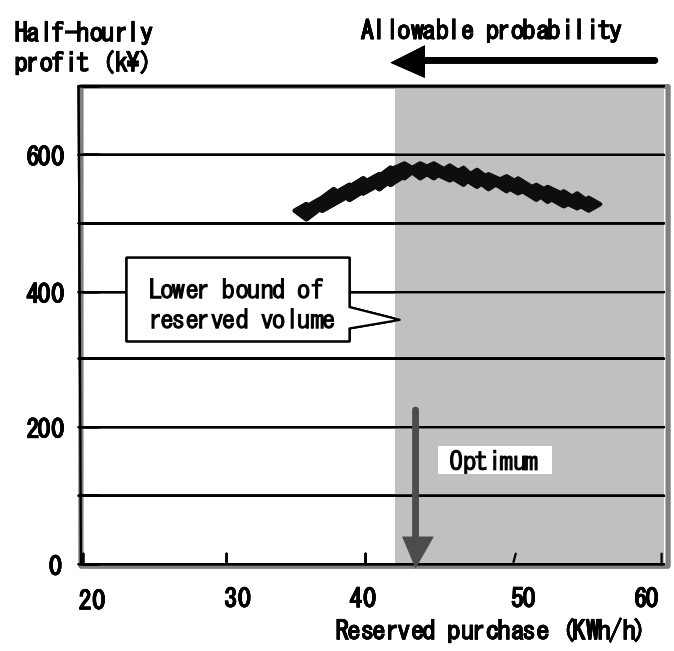

図 8 事業収益を最大とする予約調達量

Fig. 8. Optimum volume of reserved purchase
また, 緊急調達単価が増加すると, 最適予約調達量が大き くなる傾向が認められる。

図 9 に, 需要予測精度, 想定需要超過許容度 (想定需要 超過確率の上限值）を変えたときの最適予約調達量の変化 を示す。予測誤差が大きく, 想定需要超過制約上限值が小 さいと, 最適予約調達量は大きくなる。制約上限值が非常 に小さい場合，この制約条件は決定的な影響を持つことに なる。

〈4·3〉 28 時区間の最適化 多時点モデルを適用する ケースを示す。ここで, 翌日の半時間単位の 28 時区間の供 給計画に対して, 予測䛊差の大きさを標準偏差 3\%, 時区間 ごとの想定需要超過確率の上限值 $0.1 ， 5$ 時区間に亘る想定 需要超過が継続する確率の上限值 $10^{-5}$ および $10^{-6}$ という条 件下でケーススタディを実施した。図 10 に示した需要期待 值と自社生産（自社設備による発電）計画を, 前提条件と

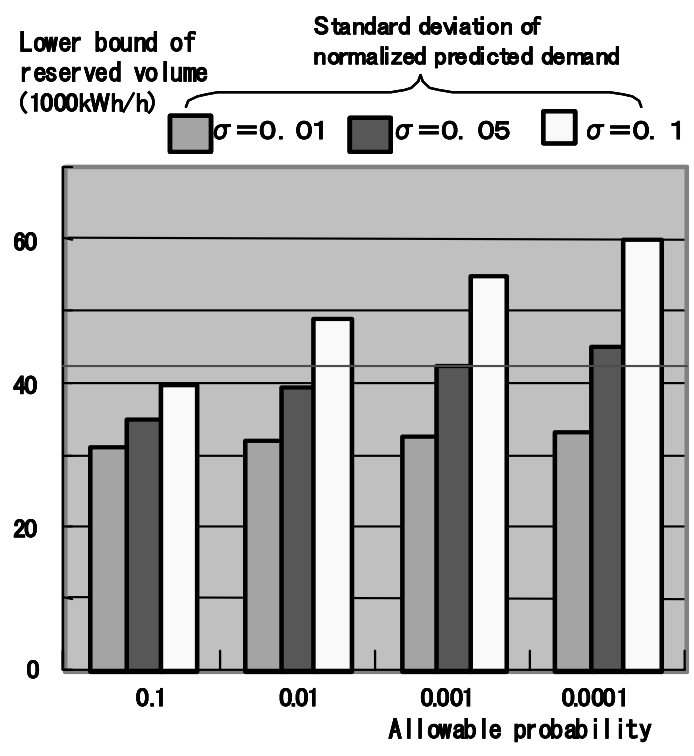

図 9 想定需要超過許容度に対応する予約調達量 Fig. 9. Lower bound of reserved volume according to allowable prob. for over-demand

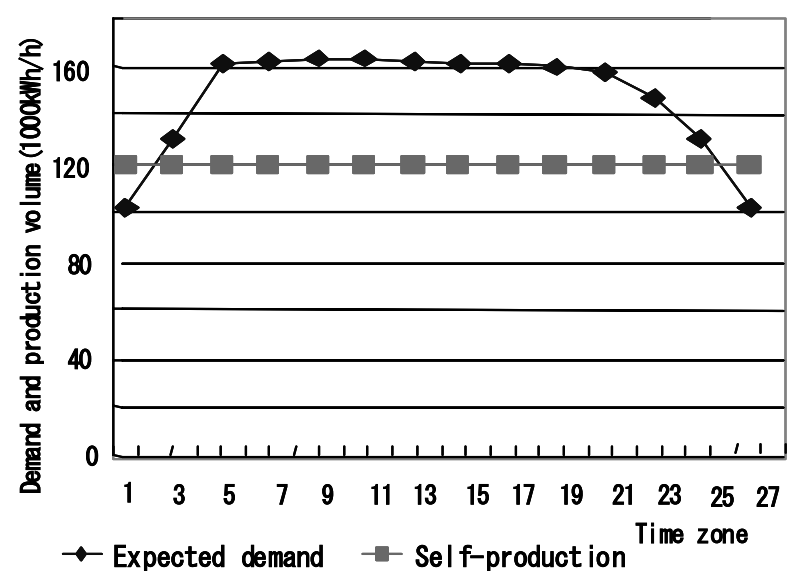

図 10 需要期待值と自社生産計画

Fig. 10. Expected demand and self-production schedule 


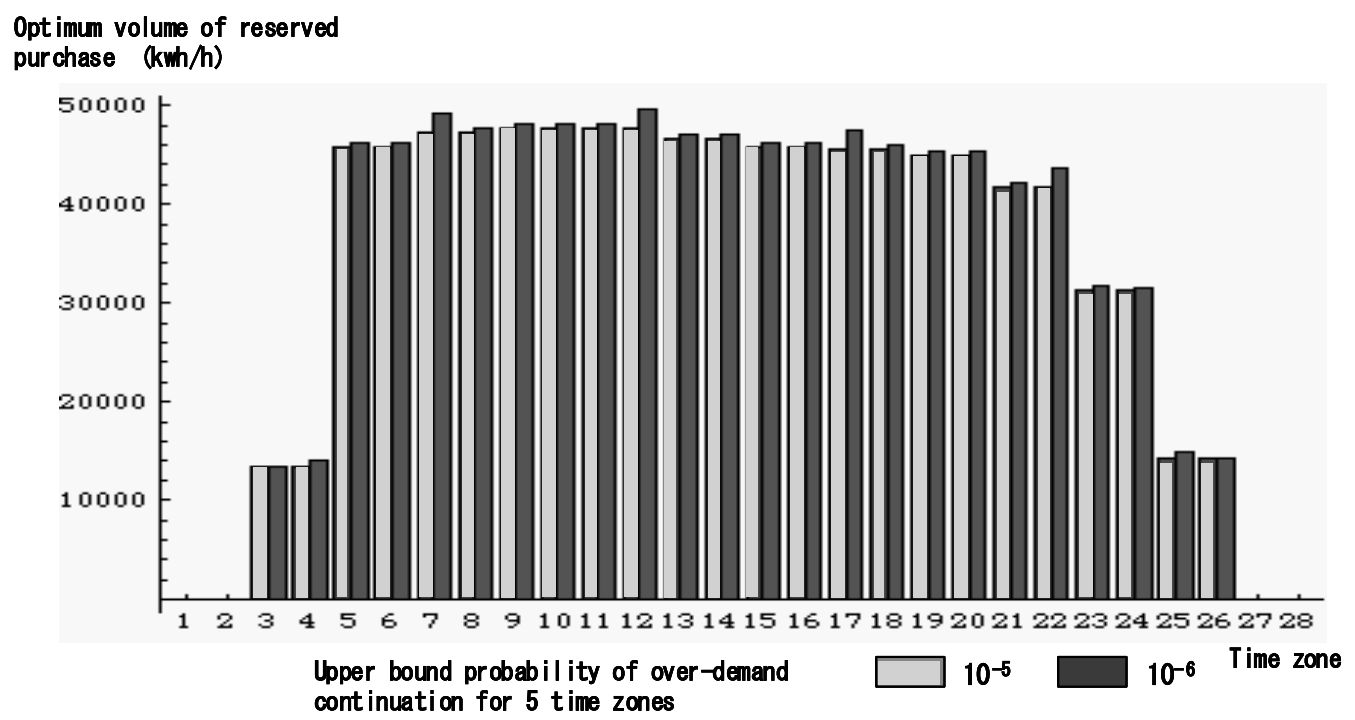

図 11 想定需要超過制約の下での最適予約調達計画

Fig. 11. The optimum volume of reserved purchase subjective to over-demand probability constraints

して運用計画を立てる。

\section{〈4·4〉 28 時区間の計算結果図 11 に計算結果の例} を示す。両端の時区閒では，予約調達量はゼロとなる。時 区間ごとの最適予約調達量は, 1 時区間モデルで言及したよ うに需要期待值をベースとして算出される值よりも供給過 剰サイドにシフトしたものとなっている。ここで, 想定需 要超過の継続に関し生起確率 $10^{-6}$ を上限とした場合に，特 定の時区間にピークを生じる特徵的なパターンが現れてい る。このようなパターンは, 制約条件により想定需要超過 が 5 時区間継続する確率を抑えていることを反映しており， 確率の上限值を $10^{-5}$ に緩和すると顕著でなくなる。

時区間 28 のケースの最適化計算は， 1 万変数規模の線形 計画であり，パソコンを用いて 20 分程度の所要時間で解が 得られる。

\section{5. まとめ}

日本の電力市場は, 2007 年度に向けて段階的に完全自由 化され，電力ビジネスに競争原理が導入される最中にある。 事業者にとっては，収益が不安定となるため，収益変動リ スクの管理が大きな課題となっている。このような背景の 下で, 電力供給のサプライチェーンの運用計画で中心課題 となる, 自社生産, 予約調達を最適化する手法を開発した。 本手法は, 電力供給を在庫機能を持たないサプライチェ ーンと捉えて, 確率計画法を用いることにより, 需要予測 誤差のため需要量と供給計画に乘離が生ずるリスクの下 で，事業収益を最大化する。手法の特徴は，(1)区分線形（折 れ線）の目的関数を用いて予約調達の過不足がコストに与 える効果をモデル化したこと，および(2)想定需要超過確率 に関する制約条件を導入して想定需要超過リスクをモデル 化したことにある。

区分線形の目的関数は，直線と絶対值関数を組み合わせ ることにより定義した。想定需要超過確率に関しては，時
区間ごとに発生する確率に対する制約, 複数の時区間に亘 って継続する確率に対する制約を導入した。

開発した手法を 1 時区間, 28 時区間のサプライチェーン の運用計画のケースに適用し, リスク管理に有効な定量的 知見を得ることができた。

・最適予約調達量は, 需要期待值を想定需要とするときの 值よりも大きくなる

・予測誤差が大きく, 想定需要超過制約上限值が小さいと, 最適予約調達量は大きくなる

・最適予約調達量が制約条件から決まる想定需要超過確率 の下限より高い領域（制約内点）で与えられる場合がある このような数值結果より，手法の有効性を確認できた。 (平成 18 年 5 月 8 日受付，平成 18 年 10 月 19 日再受付)

\section{文献}

（1） D. スミス 外（久保幹雄 監訳）：「サプライ・チェーンの設計と管 理」, 朝倉書店 (2002)

（2）貝原俊也・藤井 進:「マルチェージェントによるサプライチェーン の企業間交渉モデル」，システム/制御情報, Vol.46, No.10, pp.615-622 (2002)

（3）山木要一:「電力取引入門」, エネルギーフォーラム (2005)

(4) L. Clewlow and C. Strickland : "Energy Derivatives Pricing and Risk Management", Lacima Group Pty Limited (2000)

（5）J. ウェングラー（鮫島隆太郎 訳）：「電力取引とリスク管理一エネ ルギー市場取引入門」，エネルギーフォーラム (2003)

(6) J. Lemming : "Electricity Price Modelling for Profit at Risk Management", Riso Report (2003)

(7) N-H von der Fehr and D. Harbord : "Competition in Electricity Spot Markets: Economic Theory and International Experience", Memo. No.5/98, Dept. of Economics, Univ. of Oslo (1998)

( 8 ) B. Johnson, V. Nagali, and B. R. Romine : "Real Options Theory and the Valuation of Generation Assets", The new power markets, pp.73-101, Risk Books (1999) 
(9) 長谷川淳・田中英一:「電力の翌日最大需要予測システムの研究開発 動向」, 電学論, Vol.114, No.9, pp.835-838 (1994)

(10) 吉川元庸・澤 敏之: 「火力・用水発電所の運用計画作成手法」, 電 学論, Vol.114B, No.12, pp.1220-1226 (1994)

（11）資源エネルギー庁：「総合エネルギー調査会電気事業分科会資料」, 同庁ホームページ (2006)

(12) 今野 浩:「線形計画法」, 日科技連 (1987)

（13）小林康弘・仲田智将・真鍋裕司・清野隆正：「供給不足リスク制約の 下での生産・調達計画手法」, 2003 年日本 OR 学会秋季研究発表会 予稿, 1-I-1 (2003)

（14）小林康弘・仲田智将・真鍋裕司・三島英裕 :「供給不足リスク制約の 下での生産・調達計画手法(2)」, 2004 年日本 OR 学会春季研究発表 会予稿, 1-G-5 (2004)

（15） 小林康弘・仲田智将・真鍋裕司:「供給不足リスク制約の下での生産・ 調達計画手法(3)」, 2004 年日本 OR 学会秋季研究発表会予稿, 2-H-4 (2004)

（16）今野 浩：「理財工学 I」, 日科技連 (1995)
小 林 康 弘 (正員) 1947 年生。1975 年東京大学大学院工

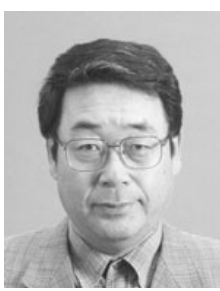

学系研究科博士課程原子力工学専攻修了。同年 （株）日立製作所に入社。1979 1980 年，米国 MIT エネルギー研究所客員研究員。1 990 年, 電 気学術振興賞論文賞受賞。現在, 同社日立研究 所において, 数理計画技術, 金融工学の研究開 発に従事。工学博士。日本金融・証券計量・工 学会, 応用時系列研究会会員。

真 鍋 裕 司 (正員) 1977 年生。2003 年早稲田大学大学院

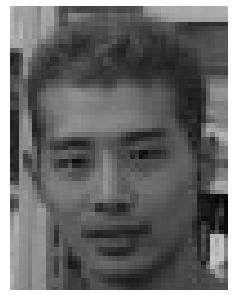
理工学究科修士課程経営システム工学専攻卒 業。同年，（株）日立製作所日立研究所に入所。 現在, リスク管理技術の研究開発に従事。品質 管理学会, 日本 OR 学会, 応用時系列研究会員。

仲 田 智 将

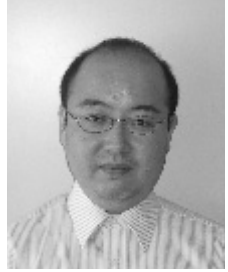

日 下智

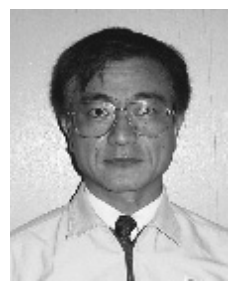

（非会員）1968 年生。1994 年早稲田大学大学 院理工学研究科修士課程工業経営学専攻。同年 （株）日立製作所日立研究所入所。金融工学技 術の研究開発に従事。2006 年より, 同社金融シ ステム事業部にて金融ビジネスコンサルティ ングを担当。日本金融・証券計量・工学会。

（非会員） 1956 年 10 月 3 日生。1980 年 3 月東 北大学工学部機械工学第二学科卒業。同年 4 月 （株）日立製作所入社。火力発電プラント計装・ 制御システム計画を担当。現在, 売電事業の推 進・運営業務に従事。火力原子力技術協会会員。 